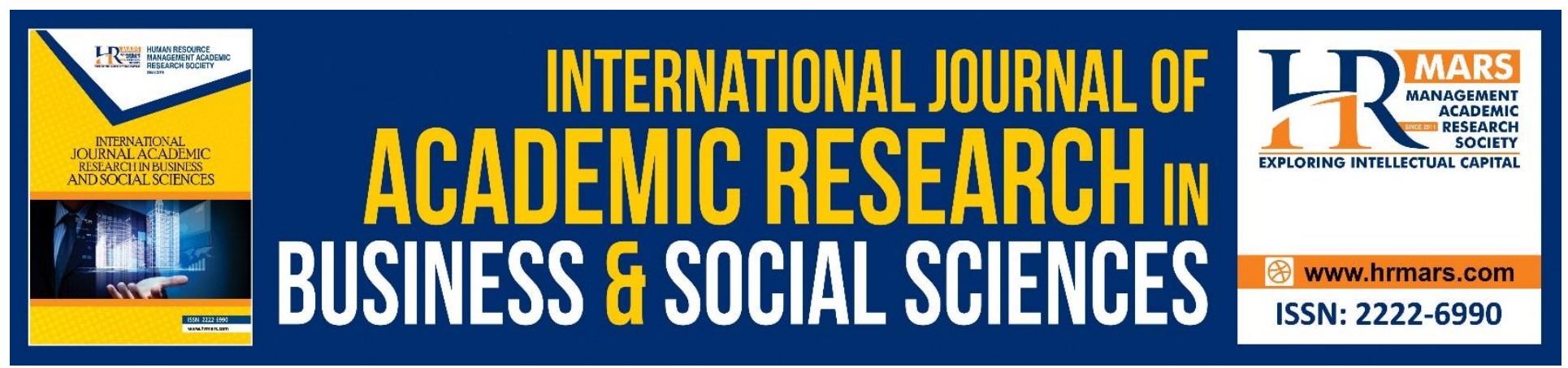

\title{
Exploration and Exploitation Strategies in SME Family Firms
}

\author{
Norshamsiah Ibrahim, Adriana Mohd Rizal, Suzilawati Kamarudin \\ and Maizaitulaidawati Md Husin
}

To Link this Article: http://dx.doi.org/10.6007/IJARBSS/v9-i1/5419

DOI: $\quad 10.6007 /$ IJARBSS/v9-i1/5419

Received: 29 Dec 2018, Revised: 25 Jan 2019, Accepted: 30 Jan 2019

Published Online: 06 Feb 2019

In-Text Citation: (Ibrahim, Rizal, Kamarudin, \& Husin, 2019)

To Cite this Article: Ibrahim, N., Rizal, A. M., Kamarudin, S., \& Husin, M. M. (2019). Exploration and Exploitation Strategies in SME Family Firms. International Journal of Academic Research in Business and Social Sciences, 9(1), 430-442.

Copyright: (C) 2019 The Author(s)

Published by Human Resource Management Academic Research Society (www.hrmars.com)

This article is published under the Creative Commons Attribution (CC BY 4.0) license. Anyone may reproduce, distribute, translate and create derivative works of this article (for both commercial and non-commercial purposes), subject to full attribution to the original publication and authors. The full terms of this license may be seen at: http://creativecommons.org/licences/by/4.0/legalcode

Vol. 9, No. 1, 2019, Pg. 430 - 442

http://hrmars.com/index.php/pages/detail/IJARBSS

JOURNAL HOMEPAGE

Full Terms \& Conditions of access and use can be found at http://hrmars.com/index.php/pages/detail/publication-ethics 


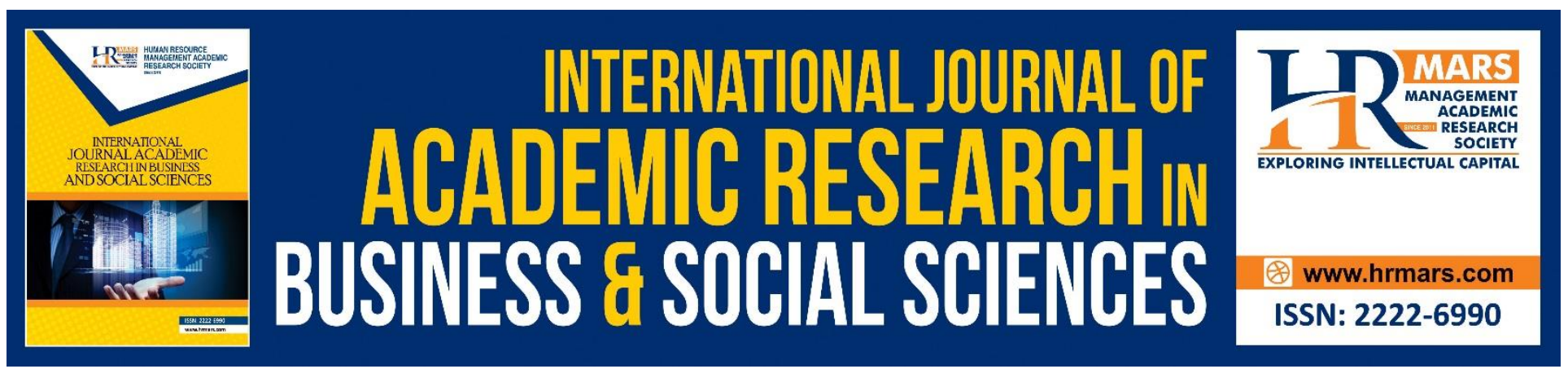

\title{
Exploration and Exploitation Strategies in SME Family Firms
}

\author{
Norshamsiah Ibrahim ${ }^{1}$, Adriana Mohd Rizal2 ${ }^{2}$, Suzilawati Kamarudin ${ }^{3}$ \\ and Maizaitulaidawati Md Husin 4 \\ 1,2,3,4,5 Azman Hashim International Business School, Level 10, Menara Razak, Universiti Teknologi \\ Malaysia, Jalan Sultan Yahya Petra, 54100 Kuala Lumpur \\ Email: adrianamohdrizal@gmail.com
}

\begin{abstract}
The survival of family firms may lie in their ability in exploiting their current competitive advantage while concurrently exploring new opportunities present in their way. However, scantiness of resources makes it hard to employ both strategies simultaneously. As such, this paper examines on how family firms decide to pursue exploitation or exploration strategies. The unique culture of family firms, for instance, long-term orientation, risk aversion, and aspiration, suggests a variety of ways to implement strategies, which could be the exploration or exploitation strategy. Hence, the main objective of this study is to review both the exploration and exploitation strategies found in the literature as practiced in family firms. In addition, this study proposes a conceptual model to further comprehend the decisions made in undertaking exploration and exploitation strategies among family firms.
\end{abstract}

Keywords: Exploration, Exploitation, Family Firms And Family Firms' Culture

\section{Introduction}

Exploration and exploitation strategies are pivotal to intensify both the long-term performance (Chen 2016; Kammerlander et al. 2015) and the survival (Hill and Birkinshaw 2014; Kollmann and Stockmann 2014) of a firm. In fact, the implementation of exploration strategy enables organizations to alter their direction and encourage them to move forward (Gupta et al. 2006), whereas exploitation strategy enables organizations to remain strong and ample in performing their current activities (Blindenbach-Driessen and Ende 2014). In addition, exploration strategy is defined as entrepreneurial action (Hitt et al. 2011) that aims to create new business opportunities by developing new products or services, processes or market (Ireland et al. 2003; Lumpkin and Dess 1996). On the other hand, exploitation strategy refers to entrepreneurial actions, inclusive of refinement, selection, efficiency, and production, besides serving as the foundation for current sources of firms in the light of competitive advantage (Ireland and Webb 2009). 
The exploration strategy leads firms to produce new products or services, besides creating new businesses and markets, as well as reaching out to new customers (Lin et al. 2016). Nevertheless, by focusing on exploration strategy only inhibits firms from generating sufficient income stream to remain sustainable in the market (Kollmann and Stockmann 2014; Lee 2015). Meanwhile, the exploitation strategy concentrates on exploiting the present competitive advantage of firms by efficiently managing its existing resources and capabilities. With exploitation strategy, firms can produce likeable products befitting to the market and thereupon, generate short-term income (Govindarajan and Trimble 2010). Nonetheless, depending solely on exploitation strategy hinders firms from being able to cope with rigorous competitors that develop new technologies and products (Chen 2016). Therefore, pursuing both strategies are indeed essential to compete in the long term, as well as to stay sustainable in the market (Kollmann and Stockmann 2014; Lin et al. 2016). However, the scantiness of resources, especially those faced by SMEs, have created a tension between exploration and exploitation strategies (Ireland and Webb 2009; Kyrgidou and Petridou 2011). Therefore, understanding on how SME family firms decide to pursue exploration and/or exploitation strategies is indeed imminent.

Exploration and exploitation strategies have been previously researched and amplified in wellestablished firms (Hill and Birkinshaw 2014; Yang et al. 2014), but few has investigated in the context of SME family firms (Moss et al. 2014; Hiebl 2015). As such, this study highlights the implementation of exploration and exploitation strategies within the context of SME family firms mainly because this area is untapped. In addition, the unique aspects of SME family firms in managing business in comparison to non-family firms make it a unique context to be studied. Besides, family firms play a crucial role in boosting the national economic development, where two third of the businesses worldwide are controlled by family firms (Family Firms Institute 2015).

Additionally, family firms contributed about 70 to 90 percent of the global gross domestic product (GDP) annually (Family Firms Institute 2015) and provided 50 to 80 percent employment worldwide (European Family Businesses Review 2012). On top of that, family firms are defined as firms that are managed and owned by family members (Deakins and Freel 2012; Sharma and Salvato 2013), sharing similar vision and commitment for future success (Hoy and Sharma 2010). These family members are usually comprised of both immediate family (i.e. parents, spouse, siblings, and children) and extended family (i.e. cousin, aunt, and uncle) (Nordqvist and Melin 2010). In fact, most of the family firms possess the potential to sustain long-term business due to their goal, which is to survive across multiple generations (Nordqvist and Melin 2010). However, a prior study indicated that 70 percent of second generation of family firms failed, while 90 percent of third generation hardly sustained their operations (Walsh 2011). Hence, it is essential to understand both the exploration and exploitation strategies since these approaches have the tendency to boost the performance of family firms. Therefore, this study reviews the literature pertaining to exploration and exploitation strategies practiced in family firms and proposes a conceptual model to comprehend how these family firms pursue exploration and exploitation strategies. 
INTERNATIONAL JOURNAL OF ACADEMIC RESEARCH IN BUSINESS AND SOCIAL SCIENCES

Vol. 9, No. 1, Jan, 2019, E-ISSN: 2222-6990 @ 2019 HRMARS

\section{Literature Review}

The exploration and exploitation employed in various organizations have emerged as prominent studies since the seminal work of organizational learning initiated by March (1991). As such, this particular notion has been applied in various contexts and interpretation such as in organizational learning (Levinthal and March 1993; Sirén et al. 2012), technological innovation (He and Wong 2004; Hughes et al. 2015), organizational design (Jansen, Volberda, and Van Den Bosch 2006), marketing (Geerts et al. 2010), strategic alliances (Yang et al. 2014), and strategic entrepreneurship (Ireland and Webb 2009; Shirokova et al. 2013). In this paper, exploration and exploitation approaches are denoted as strategies, whereby exploration is the development of a new product or service or market, while exploitation is the refinement of any existing product or service or market, which agrees with studies carried out by Patel and Chrisman (2014), as well as Piao and Zajac (2015). Furthermore, these family firms would necessarily need to employ the exploration strategy as a source for wealth creation, whereas the exploiting strategy ascertains the future competitive advantage of family firms (Foss et al. 2013; Hitt et al. 2011).

\section{Exploration}

Exploration refers to the activities carried out by an entrepreneur, including risk taking, searching, discovering, experimenting, and innovating (March 1991). Hence, exploration activities focus on developing new knowledge, products, and services for potential customers and market (Lavie et al. 2010; March 1991; Piao and Zajac 2015). These exploration strategies are established via experimentation, creativity, and broad knowledge to develop the novelty of a product or service besides creating capabilities necessary for survival and long-term prosperity (Ireland et al. 2003; March 1991; Uotila et al. 2009). Exploration strategies also have positive impact on the firms' reputation. On the other hand, the risk of failure in exploration strategies may threaten the family's control, discretion, reputation, and traditional lines of business (Chrisman and Patel 2012; GomezMejia et al. 2011). Besides, when the exploration activities are uncertain, they will imply longer time horizons by focusing on new opportunities, as well as long-term competitiveness, by keeping the firms agile in facing upcoming challenges (Hiebl 2015; Breton-Miller and Miller 2015). Therefore, it is crucial to manage potential resources and uncertainties (Ireland and Webb 2009) to attain success with exploration strategies. Hence, firms need to integrate new knowledge with the existing knowledge and realign themselves in the changing market (Ireland and Webb 2009). Nevertheless, placing too much focus on exploration strategies may harm the performance exerted by firms as they run the risk of getting stuck in unprofitable experimentation (Raisch et al. 2009; Wiklund and Shepherd 2011). Focusing solely on exploration strategies may inhibit firms from generating sufficient income, thus risking their sustainability in the market (Kollmann and Stockmann 2014; Lee 2015).

\section{Exploitation}

In contrast, exploitation strategies refer to the activities performed by entrepreneurs, for instance, refinement, production, efficient implementation, and execution (March 1991). On the other hand, exploitation activities focus on reducing variance, besides extending, and improving present products and services for the current market (Wang and Rafiq 2014). Strengthening the firm's core business through exploitation strategies may elevate the firms' reputation and increase the firms' 
performance (Patel and Chrisman 2014). In precise, these exploitation strategies are essential to strengthen the current customer relationships (Hitt et al. 2011). Moreover, these exploitation strategies are formed by utilizing both existing competitive advantage and less influential sources of uncertainty as the product or service is already well-known and accepted by the stakeholders (Ireland and Webb 2009). By focusing on familiar product markets, the potential sales growth is more predictable and potential risk is directly reduced (Patel and Chrisman 2014). However, focusing solely on exploitation may eventually diminish the possibility to detect and adopt growth opportunities deemed necessary for the long-term survival of firms (March 1991; Kollmann and Stockmann 2014). To sum up, exploration strategies are for long-term performance, whereas exploitation strategies are beneficial for short-term performance (Chen 2016; Kammerlander et al. 2015; Makkonen et al. 2014). Thus, employing both exploration and exploitation activities is indeed significant in determining the success (Shirokova et al. 2013; Stettner and Lavie 2014), the survival (Hill and Birkinshaw 2014), and the sustenance of competitive advantage among firms (Abebe and Angriawan 2014; O'Reilly and Tushman 2013). Furthermore, both strategies facilitate entrepreneurs to take strategic actions in overcoming uncertainty issues (Kyrgidou and Petridou 2011; O'Reilly and Tushman 2013; Shirokova et al. 2013), for example, volatile market and changes in government policy.

\section{Culture of Family Firms}

The importance of family firms for economic development has been long acknowledged. Family firms are rather unique in their context as they consist of family members (ownership), the family itself, and the business interaction (Chrisman et al. 2005), as proposed in the three-circle model initiated by Tagiuri and Davis (1996). This interaction between the family members builds a greater level of trust, mutuality and information exchange among them. This notion of trust among the kin is indeed beneficial for family firms especially in accumulating resources, such as transferring tacit knowledge (Breton-Miller and Miller 2015), protecting and leveraging reputation (Habbershon and Williams 1999), building strong relationships (Pearson et al. 2008), as well as slacking of resources, which support family firms to succeed even in uncertainty periods.

In precise, family members are tied with bond of affection, loyalty, and shared values (Gomez-Mejia et al. 2011). They show their loyalty and affection by giving the best performance to their firms by putting their selfish motivation away (Lubatkin et al. 2007). In fact, they are often willing to work for long hours with meagre wage (Gomez-Mejia et al. 2011; Breton-Miller and Miller 2015). Furthermore, with the training taken from family firms, family members become more confident as they enrich themselves with experiences and ability to discover the right opportunities (Sardeshmukh and Corbett 2011).

In addition, a long-term orientation potentially shapes the mindset of family members involved in the business and develop their core competencies. Long-term orientation is defined as the propensity to prioritize the long-term implication as well as the impact of decisions and actions taken that bring the result after a certain period (Lumpkin et al. 2010). Hence, family firms are said to possess long-term orientation primarily due to their desire to pass the business to the next generation (Carney 2005; Patel and Fiet 2011). 
Family firms are known as risk averse. Risk averse reflects the willingness of firms to venture into the unknown without certain knowledge of the possible outcomes (Covin and Slevin 1991). As SME family firms usually rely on their own assets, they pursue strategies that have low risk of financial failure. In fact, family firms which focus on their socioemotional wealth are usually tending to risk averse to the business opportunities that will reduce their wealth but become risk seekers when their socioemotional wealth are being threatened. Socioemotional wealth is defined as preserving their affective endowment which is non-economic goals such as firms' identity, the ability to keep family influence and control over the business and the preservation of the family dynasty and values such as firms' reputation and image (Gomez-Mejia et al. 2007; Gomez-Mejia et al. 2011; Gottardo and Moisello 2015). Due to preserving their socioemotional wealth, family firms are generally more risk averse as compared to the non-family firms (Hiebl 2015; Wilson, Wright et al. 2013).

Aspiration is defined as a strong desire to achieve something (Merriam-Webster 2018). The role of aspirations has been emphasized by behavioural theories of the firm (Cyert and March 1963), which assert that aspirations will give impact to the information processing and expectations calculations within the firms and affect the firms' performances (Basu 2004). Past research argues that the firms' decision making is guided by the discrepancy between aspiration and performance (Mazzelli 2015). It means that, if the firms' performance is below than firms' aspiration, firms are expected to use the new strategies to increase performance which usually involve high risk. However, in contrast, if firms' performance is above firms' aspiration, firms are expected to maintain the existing strategies (Shinkle 2012; Mazzelli 2015). In SME family firms, the firms' aspiration is more likely to consider socioemotional wealth and family matters (Zellweger et al. 2012a).

\section{Family Firms' Survival}

The most central issue in the family firms' performance is concerning the family firms' survival across generations (Yu et al. 2012). Family firms' survival refers to the longevity of family firms in the market as a viable entity (Colli 2012). Family firms have a long-term orientation which aim to transfer the business across generation and they need to be strategizing to ensure family firms' survival in the volatile market. Family firms are expected to have higher chance to survive in the market compared to non-family firms due to the family-oriented goals such as socioemotional wealth preservation (Gomez-Mejia et al. 2011), family reputation (Berrone et al. 2012), higher levels of social capital and lower agency costs (Wilson et al. 2013). However, past research shows that many SME family firms failed to transfer their business to the next generation. According to Zellweger et al. (2012), only 30\% of SME family firms survive till the second generation, $13 \%$ survive through the third generation, and only $3 \%$ survive beyond that.

SME family firms are unique business entity with lack of clearly defined governance structure and process for productive intergenerational discussion and decision making (Zellweger et al. 2012a). As one of the SME family firms-oriented goal is socioemotional wealth preservation, they are likely to focus on one-sided exploitation which enhance short-term performance but may reduce the chance of survival (Wilson et al. 2013; Zahra 2010). Due to this issue, prior research suggests that family firms 
need to be aligned with both exploration and exploitation strategies (Sharma and Salvato 2013; Zellweger et al. 2012b). Firms need to develop new strategic direction to survive in the volatile market. By adopting just one-sided exploitation, family firms may not be able to respond effectively to environmental changes (Kollmann and Stockmann 2014). On the contrary, focusing solely on exploration will enhance firms' ability to renew their knowledge base but if too much, firms may be trapped in the endless cycles of trial and error (Wiklund and Shepherd 2011; Wilson et al. 2013) that can incur higher cost.

\section{Exploration and Exploitation Strategies Adopted by SME Family Firms}

SME family firms would need to reflect their entrepreneurial culture to ascertain the implementation of exploring and exploiting strategies (Goel and Jones 2016). The long-term orientation in SME family firms offers the advantage of exploring and exploiting new opportunities in both static and dynamic environments (Patel and Fiat 2011). Besides, it is advantageous for SME family firms to develop core competencies due to the path dependencies which could have been developed over the years (Brigham et al. 2014; Teece 2014). In addition, Moss et al. (2014) suggests that path-dependency of either exploration or exploitation is specifically salient in SME family firms. The entrepreneurial mindset developed in the light of long-term orientation does support the comprehensive environmental screening and exploring new opportunities (König et al. 2013). Conversely, via longterm orientation, SME family firms might likely pursue the exploitation strategy due to rigidity factors by solely focusing on current expertise and capabilities primarily due to their reliance on inside resources, perspectives, and opinions (Gomez-Mejia et al. 2011).

Meanwhile, as for SME family firms, more opportunities lay at their doorsteps to explore new resources (Tsai and Lei 2016; Yang et al. 2014) mainly due to their flexible and unimpeded operations that disregard rigid procedures with involvement of external capital providers (Konig et al. 2013). SME family firms tend to have more skills and motivation in exploring new opportunities, but their limited knowledge and capabilities hinder them from exploiting those opportunities (Tsai and Lei 2016; Yang et al. 2014). However, SME family firms with high level of risk aversion may resort to exploitative activities (Abebe and Angriawan 2014; Hiebl 2015; König et al. 2013). The endeavors to preserve socioemotional wealth through family ownership and control might be detrimental to aggression as well as hinders the exploration strategy (Chrisman et al. 2015; Zellweger et al. 2012a). Therefore, family managers would try their best to avoid failure and will end up considering less risky projects (Hiebl 2015) to increase survival chances.

Nevertheless, the implementation of exploration or exploitation strategies is highly dependent on the aspiration held by the SME family firms (Patel and Chrisman 2014). Based on the socioemotional wealth considerations, SME family firms are likely to engage more in exploitation strategy due to SME family firms' traditions, reputation, and family ownership dilution when their performance meet or exceeds firms' aspiration (Patel and Chrisman 2014). On the other hand, they may turn to exploration strategies when their performance is below their aspiration to prevent loss of socioemotional wealth (Patel and Chrisman 2014). To sum up, SME family firms may opt whether the exploration or/and exploitation strategies that can increase their performance to survive in the market place. 


\section{Conceptual Framework}

The conceptual framework of this study is developed based on the discussion in section 2 above. Generally, the SME family firms' culture consists of long-term orientation, risk averse and aspiration to support the exploration and exploitation strategies engagement. The family firms culture typically reflects on the decision either to pursue with exploration or exploitation strategies or implementing both strategies simultaneously. Both exploration and exploitation strategies assist family firms to survive in the market. The conceptual framework of this study is shown in Figure 1.

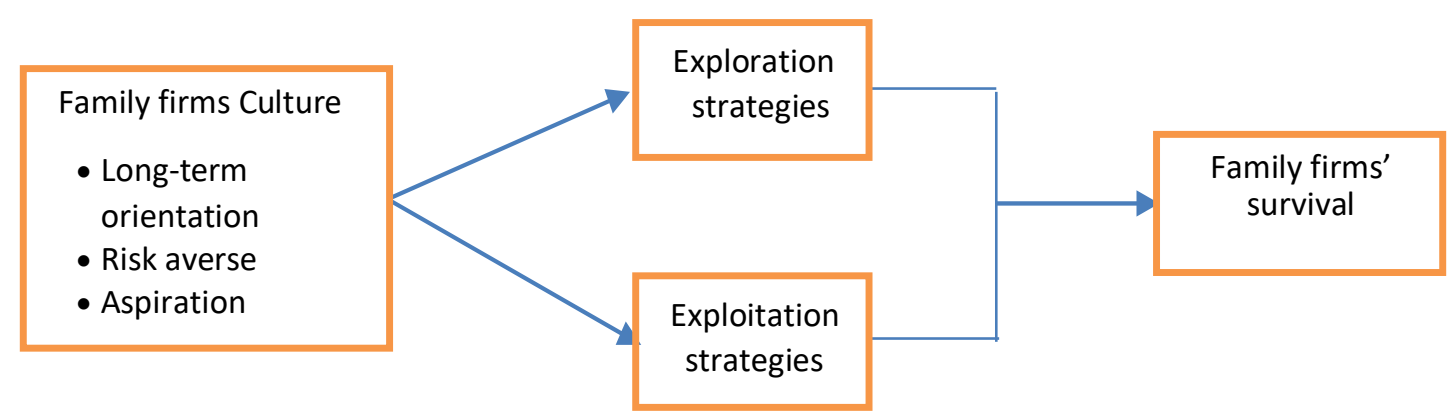

Figure 1: Exploration and exploitation strategies in SME family firm

\section{Conclusion and Future Research}

This study discusses on how exploration and exploitation strategies be employed in the SME family firms. Exploration and exploitation strategies are indeed distinct and separate organizational activities, but they are correlated. While exploitation focuses on quality and efficiency, enabling SME family firms to closely monitor and optimize current business activities; exploration investigates new opportunities, products, services, market, and customers, thus enabling SME family firms to attain long-term competition. The exploration and exploitation represent two connected elements in achieving current and future SME family firms' performance and survival. Therefore, to achieve longterm survival, these organizations must be able to continuously adapt to volatile environments besides managing both exploration and exploitation strategies in an efficient manner. The decision to pursue with exploration or/and exploitation strategies is highly dependable on the family firms' cultures which based on family firms' long-term orientation, degree of risk aversion and aspiration. All these three elements are pivotal to taken into considerations since family firms are the unique business entity that need to be comprehended. In the context of SME family firms, studies concerning exploration and exploitation strategies do provide additional information to entrepreneurs and encourage SME family firms to implement both exploration or/and exploitation strategies simultaneously. Positive family firms' culture can be the rapport to the family firms' manager to overcome resistance in pursuing the exploration and exploitation strategies. This can provide the firm with a clear starting point to achieve a long-term survival. As this paper is a conceptual paper, the future studies can be expanded by interviewing successful SME family firms, in which the result can be compiled into multiple-case studies. Such case study design could validate the proposed 
INTERNATIONAL JOURNAL OF ACADEMIC RESEARCH IN BUSINESS AND SOCIAL SCIENCES

Vol. 9, No. 1, Jan, 2019, E-ISSN: 2222-6990 (C) 2019 HRMARS

conceptual framework and directly enhance one's comprehension regarding SME family firms, especially the benefits of implementing both exploration and exploitation strategies.

\section{Acknowledgement}

The study was supported by Universiti Teknologi Malaysia and Malaysian Ministry of Higher Education under Fundamental Research Grant Scheme (FRGS), No.:R.K130000.7863.4F858, entitled - A Framework for Exploration and Exploitation Strategies in Family Firm.

\section{Corresponding Author}

Adriana Mohd Rizal

Azman Hashim International Business School, Level 10, Menara Razak, Universiti Teknologi

Malaysia, Jalan Sultan Yahya Petra, 54100 Kuala Lumpur.

E-mail: adriana.kl@utm.my

\section{References}

Abebe, M. A., \& Angriawan, A. (2014). Organizational and competitive influences of exploration and exploitation activities in small firms. Journal of Business Research, 67(3), 339-345.

Basu, A. (2004). Entrepreneurial aspirations among family business owners: an analysis of ethnic business owners in the UK. International Journal of Entrepreneurial Behavior \& Research, 10(1/2), 12-33.

Berrone, P., Cruz, C., \& Gomez-Mejia, L.R. (2012). Socioemotional wealth in family firms: Theoretical dimensions, assessment approaches, and agenda for future research. Family Business Review, 25(3), 258- 279.

Blindenbach-Driessen, F., \& Ende, J. (2014). The locus of innovation: The effect of a separate innovation unit on exploration, exploitation, and ambidexterity in manufacturing and service firms. Journal of Product Innovation Management, 31(5), 1089-1105.

Breton-Miller, L., \& Miller, D. (2015). The arts and family business: Linking family business resources and performance to industry characteristics. Entrepreneurship: Theory and Practice, 39(6), 13491370.

Brigham, K. H., Lumpkin, G. T., Payne, G. T., \& Zachary, M. A. (2014). Researching long-term orientation, a validation study and recommendations for future research. Family Business Review, 27(1), 72-88.

Carney, M. (2005). Corporate governance and competitive advantage in family-controlled firms. Entrepreneurship theory and practice, 29(3), 249-265.

Chen, Y. (2016). Dynamic Ambidexterity: How Innovators Manage Exploration and Exploitation. Business Horizons, Forthcoming.

Chrisman, J. J., Fang, H., Kotlar, J., \& De Massis, A. (2015). A note on family influence and the adoption of discontinuous technologies in family firms. Journal of Product Innovation Management, 32(3), 384-388.

Chrisman, J. J., Chua, J. H., \& Steier, L. (2005). Sources and consequences of distinctive familiness: An introduction. Entrepreneurship Theory and Practice, 29(3), 237-247. 
INTERNATIONAL JOURNAL OF ACADEMIC RESEARCH IN BUSINESS AND SOCIAL SCIENCES

Vol. 9, No. 1, Jan, 2019, E-ISSN: 2222-6990 @ 2019 HRMARS

Chrisman, J. J., \& Patel, P. C. (2012). Variations in R\&D investments of family and nonfamily firms: Behavioral agency and myopic loss aversion perspectives. Academy of management Journal, 55(4), 976-997.

Colli, A. (2012). Contextualizing performances of family firms: The perspective of business history. Family Business Review, 25(3), 243-257.

Covin, J. G., \& Slevin, D. P. (1991). A conceptual model of entrepreneurship as firm behavior. Entrepreneurship theory and practice, 16(1), 7-26.

Cyert, R. M., \& March, J. G. (1963). A behavioral theory of the firm. Englewood Cliffs, NJ, 2, 169-187.

Deakins, D., \& Freel, M. S. (2012). Entrepreneurship and Small Firms. McGraw-Hill College.

European Family Businesses [Online]. Available: http://www.europeanbusinessreview.com/. (2012) (29 March, 2017).

Family Firm Institute [Online]. Available: http://www.ffi.org/?page=GlobalDataPoints. (2015) (29 March, 2017).

Foss, N. J., Lyngsie, J., \& Zahra, S. A. (2013). The role of external knowledge sources and organizational design in the process of opportunity exploitation. Strategic Management Journal, 34(12), 1453-1471

Geerts, A., Blindenbach-Driessen, F., \& Gemmel, P. (2010, August). Achieving A Balance Between Exploration and Exploitation in Service Firms: A Longitudinal Study. In Academy of Management Proceedings, 2010(1), 1-6. Academy of Management.

Goel, S., \& Jones III, R. J. (2016). Entrepreneurial exploration and exploitation in family business: a systematic review and future directions. Family Business Review, 29(1), 94-120.

Gomez-Mejia, L. R., Cruz, C., Berrone, P., \& De Castro, J. (2011). The bind that ties: Socioemotional wealth preservation in family firms. The Academy Of Management Annals, 5(1), 653-707.

Gomez-Mejia, L.R., Haynes, K.T., Nunez-Nickel, M., Jacobson, K.J.L. and Moyano-Fuentes, J. (2007). Socioemotional wealth and business risks in family-controlled firms, evidence from Spanish olive oil mills, Administrative Science Quarterly, 52 (1), 106-137.

Gottardo, P., \& Moisello, A. M. (2015). The impact of socioemotional wealth on family firms' financial performance. Problems and Perspectives in Management, 13(1), 67-77.

Govindarajan, V., \& Trimble, C. (2010). The CEO's role in business model reinvention. Harvard Business Review, 89(1-2), 108-14.

Gupta, A. K., Smith, K. G., \& Shalley, C. E. (2006). The interplay between exploration and exploitation. Academy of Management Journal, 49(4), 693-706.

Habbershon, T. G., \& Williams, M. L. (1999). A resource-based framework for assessing the strategic advantages of family firms. Family business review, 12(1), 1-25.

He, Z. L., \& Wong, P. K. (2004). Exploration vs. exploitation: An empirical test of the ambidexterity hypothesis. Organization Science, 15(4), 481-494.

Hiebl, M. R. (2015). Family involvement and organizational ambidexterity in later-generation family businesses: A framework for further investigation. Management Decision, 53(5), 1061-1082.

Hill, S. A., \& Birkinshaw, J. (2014). Ambidexterity and survival in corporate venture units. Journal of Management, 40(7), 1899-1931. 
INTERNATIONAL JOURNAL OF ACADEMIC RESEARCH IN BUSINESS AND SOCIAL SCIENCES

Vol. 9, No. 1, Jan, 2019, E-ISSN: $2222-6990$ @ 2019 HRMARS

Hitt, M. A., Ireland, R. D., Sirmon, D. G., \& Trahms, C. A. (2011). Strategic entrepreneurship: creating value for individuals, organizations, and society. The Academy of Management Perspectives, 25(2), 57-75.

Hoy, F., \& Sharma, P. (2010). Entrepreneurial family firms. Pearson College Division.

Hughes, M., Hughes, P., Morgan, R. E., \& Hodgkinson, I. R. (2015). Organizing strategic entrepreneurship to enable product innovation in new and young technology-based firms.

Ireland, R. D., \& Webb, J. W. (2009). Crossing the great divide of strategic entrepreneurship: Transitioning between exploration and exploitation. Business Horizons, 52(5), 469-479.

Ireland, R. D., Hitt, M. A., \& Sirmon, D. G. (2003). A model of strategic entrepreneurship: The construct and its dimensions. Journal of Management,29(6), 963-989.

Jansen, J. J., Van Den Bosch, F. A., \& Volberda, H. W. (2006). Exploratory innovation, exploitative innovation, and performance: Effects of organizational antecedents and environmental moderators. Management Science, 52(11), 1661-1674.

Kammerlander, N., Burger, D., Fust, A., \& Fueglistaller, U. (2015). Exploration and exploitation in established small and medium-sized enterprises: The effect of CEOs' regulatory focus. Journal of Business Venturing, 30(4), 582-602.

König, A., Kammerlander, N., \& Enders, A. (2013). The family innovator's dilemma: How family influence affects the adoption of discontinuous technologies by incumbent firms. Academy of Management Review, 38(3), 418-441.

Kollmann, T., \& Stöckmann, C. (2014). Filling the entrepreneurial orientation-performance gap: The mediating effects of exploratory and exploitative innovations. Entrepreneurship Theory and Practice, 38(5), 1001-1026.

Kyrgidou, L. P., \& Petridou, E. (2011). The effect of competence exploration and competence exploitation on strategic entrepreneurship. Technology Analysis \& Strategic Management, 23(6), 697-713.

Lavie, D., Stettner, U., \& Tushman, M. L. (2010). Exploration and exploitation within and across organizations. The Academy of Management Annals, 4(1), 109-155.

Lee, K. C. (2015). Dynamic resource allocation for exploitation and exploration with ambidexterity: Logical mechanism and simulations. Computers in Human Behavior, 42, 120-126.

Levinthal, D. A., \& March, J. G. (1993). The myopia of learning. Strategic Management Journal, 14(S2), 95-112.

Lin, H. E., McDonough, E. F., Yang, J., \& Wang, C. (2016). Aligning Knowledge Assets for Exploitation, Exploration, and Ambidexterity: A Study of Companies in High- Tech Parks in China. Journal of Product Innovation Management, 34(2), 122-140.

Lubatkin, M. H., Ling, Y., \& Schulze, W. S. (2007). An organizational justice-based view of self-control and agency costs in family firms. Journal of Management Studies, 44(6), 955-971.

Lumpkin, G. T., \& Dess, G. G. (1996). Clarifying the entrepreneurial orientation construct and linking it to performance. Academy of management Review, 21(1), 135-172.

Lumpkin, G. T., Brigham, K. H., \& Moss, T. W. (2010). Long-term orientation: Implications for the entrepreneurial orientation and performance of family businesses. Entrepreneurship and Regional Development, 22(3-4), 241-264. 
INTERNATIONAL JOURNAL OF ACADEMIC RESEARCH IN BUSINESS AND SOCIAL SCIENCES

Vol. 9, No. 1, Jan, 2019, E-ISSN: 2222-6990 @ 2019 HRMARS

Makkonen, H., Pohjola, M., Olkkonen, R., \& Koponen, A. (2014). Dynamic capabilities and firm performance in a financial crisis. Journal of Business Research, 67(1), 2707-2719.

March, J. G. (1991). Exploration and exploitation in organizational learning. Organization Science, 2(1), 71-87.

Mazzelli, A. (2015). Behavioural theory and the family business. Theoretical Perspectives on Family Businesses, 35.

Merriam Webster Incorporation. [Online]. Available: https://www.merriamwebster.com/dictionary/aspiration. (2017) (29 March 2017).

Moss, T. W., Payne, G. T., \& Moore, C. B. (2014). Strategic consistency of exploration and exploitation in family businesses. Family Business Review,27(1), 51-71.

Nordqvist, M., \& Melin, L. (2010). Entrepreneurial families and family firms. Entrepreneurship and Regional Development, 22(3-4), 211-239.

O'Reilly, C. A., \& Tushman, M. L. (2013). Organizational ambidexterity: Past, present, and future. The Academy of Management Perspectives, 27(4), 324-338.

Patel, P. C., \& Chrisman, J. J. (2014). Risk abatement as a strategy for R\&D investments in family firms. Strategic Management Journal, 35(4), 617-627.

Patel, P. C., \& Fiet, J. O. (2011). Knowledge combination and the potential advantages of family firms in searching for opportunities. Entrepreneurship Theory and Practice, 35(6), 1179-1197.

Pearson, A. W., Carr, J. C., \& Shaw, J. C. (2008). Toward a theory of familiness: A social capital perspective. Entrepreneurship theory and practice, 32(6), 949-969.

Piao, M., \& Zajac, E. J. (2015). How exploitation impedes and impels exploration: Theory and evidence. Strategic Management Journal.

Raisch, S., Birkinshaw, J., Probst, G., \& Tushman, M. L. (2009). Organizational ambidexterity: Balancing exploitation and exploration for sustained Performance. Organization science, 20(4), 685-695.

Sardeshmukh, S. R., \& Corbett, A. C. (2011). The duality of internal and external development of successors: opportunity recognition in family firms. Family Business Review, 24(2), 111-125.

Sharma, P., \& Salvato, C. (2013). Family firm longevity: A balancing act between continuity and change. A global revolution: The endurance of large family businesses around the world, 34-56.

Shinkle, G. A. (2012). Organizational aspirations, reference points, and goals: Building on the past and aiming for the future. Journal of Management, 38(1), 415-455.

Shirokova, G., Vega, G., \& Sokolova, L. (2013). Performance of Russian SMEs: Exploration, exploitation and strategic entrepreneurship. Critical perspectives on international business, 9(1/2), 173-203.

Sirén, C. A., Kohtamäki, M., \& Kuckertz, A. (2012). Exploration and exploitation strategies, profit performance, and the mediating role of strategic learning: Escaping the exploitation trap. Strategic Entrepreneurship Journal,6(1), 18-41.

Stettner, U., \& Lavie, D. (2014). Ambidexterity under scrutiny: Exploration and exploitation via internal organization, alliances, and acquisitions. Strategic Management Journal, 35(13), 19031929.

Teece, D. J. (2014). A dynamic capabilities-based entrepreneurial theory of the multinational enterprise. Journal of International Business Studies, 45(1), 8-37.

Tagiuri, R., \& Davis, J. (1996). Bivalent attributes of the family firm. Family business review, 9(2), 199208. 
INTERNATIONAL JOURNAL OF ACADEMIC RESEARCH IN BUSINESS AND SOCIAL SCIENCES

Vol. 9, No. 1, Jan, 2019, E-ISSN: 2222-6990 (C) 2019 HRMARS

Tsai, I. C., \& Lei, H. S. (2016). The Importance and Satisfaction of Collaboartive Innovation for Strategic Entrepreneurship. Eurasia Journal of Mathematics, Science \& Technology Education, 12(3), 569582.

Uotila, J., Maula, M., Keil, T., \& Zahra, S. A. (2009). Exploration, exploitation, and financial performance: analysis of S\&P 500 corporations. Strategic Management Journal, 30(2), 221-231.

Walsh, G. (2011). Family business succession managing the all-important family component: Who says the family business won't make it to the next generation? Canada: KPMG LLP (KPMG International).

Wang, C. L., \& Rafiq, M. (2014). Ambidextrous Organizational Culture, Contextual Ambidexterity and New Product Innovation: A Comparative Study of UK and C hinese High-tech Firms. British Journal of management, 25(1), 58-76.

Wiklund, J., \& Shepherd, D. A. (2011). Where to from here? EO- as- experimentation, failure, and distribution of outcomes. Entrepreneurship Theory and Practice, 35(5), 925-946.

Wilson, N., Wright, M., \& Scholes, L. (2013). Family business survival and the role of boards. Entrepreneurship Theory and Practice, 37(6), 1369-1389.

Yang, H., Zheng, Y., \& Zhao, X. (2014). Exploration or exploitation? Small firms' alliance strategies with large firms. Strategic Management Journal, 35(1), 146-157.

Yu, A., Lumpkin, G.T., Sorenson, R.L., \& Brigham, K.H. (2012). The landscape of family business outcomes: A summary and numerical taxonomy of dependent variables. Family Business Review, 25(1), 33-57.

Zahra, S. A. (2010). Harvesting family firms' organizational social capital: A relational perspective. Journal of Management Studies, 47(2), 345-366.

Zellweger, T.M., Kellermanns, F.W., Chrisman, J. J., and Chua, J. H. (2012a). Family Control and Family Firm Valuation by Family CEOs: The Importance of Intentions for Transgenerational Control. Organization Science, 23 (3), 851-868.

Zellweger, T. M., Nason, R. S., \& Nordqvist, M. (2012b). From longevity of firms to transgenerational entrepreneurship of families: Introducing family entrepreneurial orientation. Family Business Review, 25(2), 136-155. 